\title{
Abraham w Dziejach Apostolskich
}

\begin{abstract}
Abraham to, obok Mojżesza, postać Starego Testamentu najczęściejprzywoływana przez autorów Nowego Testamentu. Wielokrotnie pojawia się w literaturze biblijnej poza Księgą Rodzaju, a także w apokryfach. Główny motyw związany z tym patriarchą to przymierze. Tradycja o Abrahamie odgrywa zasadniczą rolę w definiowaniu relacji przymierza Jahwe z Jego ludem. Podstawowy tekst z historii Abrahama, do którego nawiązują późniejsze pisma, to słowa skierowane do patriarchy na początku jego misji: „Wyjdź z twojej ziemi rodzinnej i z domu twego ojca do kraju, który ci ukażę. Uczynię bowiem z ciebie wielki naród, będę ci błogosławił i twoje imię rozsławię: staniesz się błogosławieństwem. Będę błogosławił tym, którzy ciebie błogosławić będą, a tym, którzy tobie będą złorzeczyli, i ja będę złorzeczył. Przez ciebie będą otrzymywały błogosławieństwo ludy całej ziemi" (Rdz 12,1-3). Abram jest ukazany tutaj jak ojciec założyciel nowego ludu, w którym błogosławieństwo znajduje nie tylko Izrael, ale także wszystkie narody na ziemi. Potwierdza to również zmiana imienia z Abrama na Abraham („ojciec mnóstwa” - Rdz 17,5) związana z opisem zawarcia przymierza.

W obietnicy danej Abrahamowi (12,1-3) zostają ukazane po raz pierwszy partykularne i uniwersalne aspekty przymierza z Abrahamem, które są też obecne w dwóch następnych perykopach poświęconych przymierzu w Rdz 15 i 17, a także w Rdz 22, kiedy to Bóg ocala życie Izaaka. Motyw przymierza z Abrahamem łączy się również z tematem wyjścia Izraela z Egiptu, wyznaczając tym samym paradygmat oswobodzenia ludu przez Boga jako konsekwencji obietnicy złożonej Abrahamowi w związku z przymierzem (Rdz 15,13nn)1. Jest to schemat pojawiający się w Bożej historii zbawienia, polegający na tym,
\end{abstract}

\footnotetext{
${ }^{1}$ Paradygmat ten powraca w relacji o zniszczeniu Sodomy i Gomory, kiedy to Bóg ocala rodzinę Lota, pamiętając o obietnicy danej Abrahamowi.
} 
że kolejne akty Bożego wyzwolenia nierozdzielnie wiążą się z obietnicą daną Abrahamowi. Powtórzenie przez Boga Izaakowi (Rdz 26,2-6) i Jakubowi (Rdz 28,13-15) obietnicy towarzyszącej przymierzu w sposób bezpośredni łączy tę obietnicę z Izraelem i staje się podstawą ciągłości relacji przymierza z narodem izraelskim, zasadniczo charakteryzując Boga Izraela jako Boga Abrahama, Boga Izaaka i Boga Jakuba². Za każdym razem, gdy Bóg zostaje przedstawiony jako Bóg Abrahama, Izaaka i Jakuba, tym samym zostaje przywołane przymierze z Abrahamem.

Poza Pięcioksięgiem również prorocy i psalmiści dają świadectwo znaczącej roli, jaką w relacji Izraela z Bogiem odgrywa pamięć o Abrahamie. Przeżywając sytuacje udręczenia i niepewności, Izrael czerpie nadzieję na przetrwanie i powrót do Ziemi Obiecanej ze wspomnienia Bożej obietnicy towarzyszącej przymierzu z Abrahamem (zob. Iz 29,22; 41,8; 51,2; Mi 7,20; Ps 105,6.9.42).

Późniejsze księgi Starego Testamentu oprócz partykularnego aspektu przymierza podkreślają jego uniwersalizm i mówią o powszechnym królowaniu Jahwe i powszechnym ojcostwie Abrahama. Szczególnie w tekstach Iz, które wskazują na lud Izraela jako na potomstwo Abrahamowe (Iz 29,22; 41,8; 51,2; $63,12)$, pojawia się kontekst przyszłej odbudowy Izraela ${ }^{3}$. Ponowne jego zgromadzenie ze wszystkich zakątków ziemi nawiązuje do złożonej patriarchom Bożej obietnicy ponownego zebrania rozproszonych potomków Abrahama z czterech stron świata (Rdz 13,14-15; 28,14). Prócz tego, księga Iz antycypuje eschatologiczne zgromadzenie narodów (Iz 52,10), a zbawienie potomstwa Abrahamowego wiąże ze zbawieniem innych narodów (Iz 51,1-4).

Nawet z księgami, w których stawia się nacisk na obronę tożsamości narodowej Żydów z przymierzem Abrahamowym, są związane elementy uniwersalistyczne. W Księdze Syracha Abraham jest nazwany „ojcem mnóstwa narodów”: „Dlatego Bóg przysięgą zapewnił go, że w jego potomstwie będą błogosławione narody, że go rozmnoży jak proch ziemi, jak gwiazdy wywyższy jego potomstwo, że da mu dziedzictwo od morza aż do morza i od Rzeki aż po krańce ziemi" (Syr 44,21). Jednak ojcostwo Abrahama jest sprowadzone do dwóch zasadniczych elementów, które stają się wyróżnikiem przynależności do narodu wybranego i stają się gwarantem obietnic Bożych. Są nimi: zachowanie Prawa i obrzezanie.

\footnotetext{
${ }^{2}$ Por. W.A. Van Gemeren, The Story of Salvation from Creation to the New Jerusalem, Grand Rapids 1988, 104-105.

3 Izraelici także wtedy, gdy doznawali ucisku ze strony władców pogańskich, sięgali do doskonałego przykładu wiary i posłuszeństwa, jaki dostrzegli w życiu Abrahama, zwłaszcza jego wiary w obietnicę potomstwa i ziemi $(\operatorname{Rdz} 15,6)$ oraz posłuszeństwa okazanego w związku $\mathrm{z}$ ofiarą Izaaka (Rdz 22). W trudnych momentach historycznych nasilały się dawne wspomnienia o Abrahamie.
} 


\section{Rozwój tradycji o Abrahamie}

W literaturze okresu międzytestamentowego wątki Abrahamowe wykazują zarówno podobieństwa, jak i rozbieżności wobec przekazu Starego Testamentu. Abraham nadal jest przedstawiany jako ojciec założyciel narodu, a obietnica Jahwe towarzysząca przymierzu jest ukazana jako fundament przywrócenia narodowości Izraela i odnowienia jego związku z Bogiem praojców. Jednak w kontekście wewnętrznych i zewnętrznych konfliktów partykularne i uniwersalistyczne aspekty przymierza z Abrahamem stopniowo rozwijają się. Fizyczne pochodzenie od Abrahama przestało być wystarczającą gwarancją zachowania relacji przymierza z Jahwe. Tradycje te są rozwijane m.in. w literaturze apokryficznej związanej z osobą patriarchy ${ }^{4}$. Literatura judaistyczna okresu Drugiej Świątyni podkreśla i przekazuje ciągłość izraelskiej przeszłości, teraźniejszości i przyszłości „w naszym ojcu Abrahamie”. Postać patriarchy ma cechy postaci eschatologicznej i jest ukazana nie tylko jako indywidualność minionej epoki, ale również jako ojciec, do którego w przyszłym świecie przyjdą wszyscy wierni Żydzi.

Pisma Józefa Flawiusza ${ }^{5}$ i Filona $^{6}$ również prezentują Abrahama jako założyciela narodu. Obaj autorzy podkreślają, iż patriarcha był pierwszym monoteistą, który wierzył w jednego Stworzyciela rodzaju ludzkiego ${ }^{7}$. Mimo to ich dzieła charakteryzuje brak biblijnej koncepcji obietnicy towarzyszącej przymierzu i danej Abrahamowi. Nieobecność motywu przymierza w pismach Józefa i Filona wynika z celu apologetycznego, jaki przyświecał ich dziełom w czasie, gdy większość ich czytelników stanowili poganie. Wprawdzie Flawiusz i Filon przekazują uniwersalny wizerunek Abrahama, który ma być przykładem i wzorcem dla wszystkich narodów, ale w prezentacji tej nie czerpią z kontekstu przymierza, jaki jest obecny w Rdz, lecz $\mathrm{z}$ hellenistycznych ideałów świata grecko-rzymskiego ${ }^{8}$.

Główne tematy Starego Testamentu związane z Abrahamem są kontynuowane w Nowym Testamencie, wykazując charakterystyczne rozszerzenia

${ }^{4}$ Zob. Testament Abrahama, Apokalipsa Abrahama, Księga Jubileuszów.

5 Por. Dawne dzieje Izraela (= Ant.) 1,148-257: tł. Z. Kubiak - J. Radożycki, wstęp E. Dąbrowski - W. Malej, kom. J. Radożycki, Warszawa 1993; tenże, Wojna żydowska (= Bell.) 4,531 i 5,380: tł., wstęp i kom. J. Radożycki, Poznań 1980.

${ }^{6}$ Zob. De Abrahamo; De Migratione Abrahami, De Virtutibus. Por. E. Birnbaum, The Place of Judaism In Philo's Thought, Atlanta 1996.

${ }^{7}$ Zob. Ant. 1,155; De Migratione Abrahami 70.

8 Zob. L.H. Feldman, Hellenization in Josephus' "Jewish Antiquities": The Portrait of Abrahama, w: Josephus, Judaism, and Christianity, red. L.H. Feldman - G. Hata, Detroit 1987, 133-153; P. Borgen, Philo of Alexandria. An Exegete for his Time, Leiden 1997, 63nn. 
i reinterpretacje9 . Jak już zaznaczono, Abraham jest po Mojżeszu najczęściej przypominaną postacią Starego Testamentu, dotyczy to szczególnie związanego z nim motywu przymierza i obietnicy ${ }^{10}$. Oprócz Ewangelii Janowej bardzo często nawiązuje do Abrahama św. Paweł (w Liście do Rzymian i Galatów), a także autor listu do Hebrajczyków ${ }^{11}$ oraz Ewangelia Łukasza (15 razy) ${ }^{12}$ i Dzieje Apostolskie $(7 \mathrm{razy})^{13}$.

W Ewangeliach podkreślane jest jego znaczenie w historii zbawienia (Mt 8,11 i par.; Mk 12,26 i par.; Łk 16,22nn; 19,9). Abraham nadal jest ukazywany jako ojciec Izraelitów „według ciała”, a oni są jego synami (Mt 3,9; Łk 13,16; 16,24; Dz 13,26; Rz 11,1). Jednakże autor Ewangelii Janowej kwestionuje przesadne podkreślanie przez Żydów ich pochodzenia od Abrahama i znaczenie jego roli w kontekście przyjścia Jezusa Chrystusa (J 8,52-59). Na Abrahama można się powoływać jako na przykład posłuszeństwa wobec woli Bożej (J 8,39n i Jk 2,21-24). Jednak autorzy Nowego Testamentu odrzucają poglądy, że może on wybawić swoje dzieci od Hadesu (Łk 16,26). Postać Abrahama i jego ojcostwo w Nowym Testamencie podlega reinterpretacji. Nie chodzi już o pochodzenie fizyczne. Naturalni spadkobiercy Abrahama mogą zostać pozbawieni dziedzictwa (Mt 8,11-12; J 8,39-40). Św. Paweł w kontekście dyskusji z judaizującym chrześcijaństwem wskazuje, że Abraham to przykład człowieka, który został usprawiedliwiony przez swoją wiarę (Rz 4,1nn; Ga 3,6nn) i dlatego chrześcijanie zarówno pochodzenia żydowskiego, jak i nieżydowskiego mogą być uznani za prawdziwe dzieci Abrahama i spadkobierców obietnicy Abrahamowej (Rz 4,1.12; 9,7n; Ga 3,7.9.29; 4,22nn; por. Jk 2,21; Hbr 2,16; 6,13nn). Dzięki przyjściu Jezusa Chrystusa przysięga, którą Bóg złożył „ojcu naszemu Abrahamowi” (Łk 1,73), potwierdzona obietnicami (Dz 7,5-6), jest teraz rozszerzona na wszystkich, którzy tak jak Izaak są „dziećmi obietnicy” (Ga 4,28). Bóg jest „Bogiem Abrahama” (Mk 12,26; Dz 7,32), a Abraham jest nazwany przyjacielem Boga (Jk 2,23). Ten sam Bóg wsławia swego sługę Jezusa (Dz 3,13). Abraham jest emfatycznie nazywany „ojcem nas wszystkich”, to znaczy tych, którzy wierzą dzięki wierze Abrahama (Rz 4,16; Ga 3,7-9.14) ${ }^{14}$.

\footnotetext{
${ }^{9}$ Abraham, w: The New International Dictionary of Old Testament Theology and Exegesis (= NIDOTTE), red. W. Van Gemeren, Grand Rapids, MI 1989-2001 [wersja elektroniczna 2.8].

${ }^{10}$ Abraham w NT; zob. G. Kittel - G. Friedrich, The Theological Dictionary of the New Testament, Grand Rapids, MI 2000 [wersja elektroniczna].

${ }^{11}$ W jedenastu księgach NT można znaleźć aż 83 odniesienia do Abrahama. Poza Łk i Dz występuje u: Mt - 7 razy $(1,1.2 .17 ; 3,9 ; 8,11 ; 22,32)$; Mk - 1 raz $(12,26) ; \mathrm{J}-11$ razy $(8,33.37 .39$ .40.52.53.56.57.58); Rz - 9 razy (4,1.2.3.9.12.13.16.18; 9,7.8; 11,1); 2 Kor - 1 raz $(11,22)$; Ga 9 razy $(3,6.7 .8 .9 .14 .16 .18 .29 ; 4,22) ; \mathrm{Hbr}-10$ razy $(2,16 ; 6,13.15 ; 7,1.2 .4 .5 .6 .9 .10 ; 11,8.11 .17 .19)$; Jk 2 razy $(2,21.23)$ i $1 \mathrm{P}-1$ raz $(3,6)$. W niektórych miejscach występuje dwa razy.

${ }^{12}$ Łk 1,55.73; 3,8.34; 13,16.28; 16,22.23.24.25.29.30; 19,9; 20,37.

${ }^{13}$ Dz 3,13.25; 7,2.16n.32; 13,26.

${ }^{14}$ Zob. NIDOTTE. Por. F.E. Wieser, Die Abrahamvorstellungen im Neuen Testament, Bern 1987.
} 
Z krótkiego przeglądu tekstów dotyczących patriarchy w Nowym Testamencie wynika, że oprócz św. Pawła charakterystyczną interpretację obietnicy i błogosławieństwa Abrahama przedstawia ewangelista Łukasz w swoim podwójnym dziele (Łk-Dz). W jego pismach, które ukazują rozwój misji Kościoła, pobrzmiewa echo spełnienia obietnicy Boga danej Abrahamowi, czyli udzielenia błogosławieństwa wszystkim narodom ziemi. Szczególnie narracja Dziejów przedstawia rozsze-rzenie zbawienia z jednego narodu, jakim jest Izrael, na wiele narodów, a zatem do perspektywy uniwersalistycznej ${ }^{15}$. Ten kierunek jest już obecny w przymierzu zawartym z Abrahamem, zinterpretowanym przez Łukasza w kontekście wyda-rzenia Jezusa Chrystusa i rozwoju Kościoła.

\section{Rozwój misji Kościoła a obietnica Abrahama w Dziejach Apostolskich}

Perspektywa rozszerzenia zbawienia na wszystkie narody jest obecna już od początku Ewangelii Łukasza, poczynając od świadectwa Symeona: „Bo moje oczy ujrzały Twoje zbawienie, któreś przygotował wobec wszystkich narodów: światło na oświecenie pogan i chwałę ludu Twego, Izraela" (Łk 2,30-32), aż po jej zakończenie: „w imię Jego głoszone będzie nawrócenie i odpuszczenie grzechów wszystkim narodom, począwszy od Jerozolimy" (Łk 24,47). Powtórzenie tej idei widać też w Dziejach Apostolskich, np.: Tak bowiem nakazał nam Pan: Ustanowiłem Cię światłościq dla pogan, abyś był zbawieniem aż po krańce ziemi (Dz 13,47).

Choć patriarcha jest przypomniany w Dziejach Apostolskich bezpośrednio tylko 7 razy, to ma to miejsce w trzech mowach głównych postaci tego pisma, czyli w mowie Piotra (3,12-26), Szczepana (7,2-53) i Pawła (Dz 13,16-47). Każdy z nich nawiązuje do Abrahama, aby wskazać uzasadnienie misji Kościoła, ta zaś zgadza się z ogólnym przesłaniem przymierza Abrahama, łącząc je równocześnie z innymi głównymi tradycjami Starego Testamentu. Oprócz tych

${ }^{15} \mathrm{Na}$ ten temat powstała praca doktorska w Trinity Evangelical Divinity School. Jej autor poprzedza teksty Łukaszowe dokładną analizą fragmentów związanych z Abrahamem w Starym Testamencie, w literaturze okresu Drugiej Świątyni, a także Nowym Testamencie. Główny cel, który sobie stawia autor pracy, to ukazanie rozwoju motywu Abrahama w Ewangelii Łukasza i Dziejach. W streszczeniu podkreśla wagę tego tematu u Łk: „Luke’s focus is God’s covenant promise to Abraham, who is the progenitor of all Hebrew race. By patterning the expansion of the blessings from a national aspect to universal aspect in the development of the Abraham narrative, Luke place the theme of «from Israel to the nations» at heart of his own narrative constructions", zob. H.M. Kim, „From Israel to the Nations”. A Critical Study of the Abraham Motif in Luce-Acts, Deerfield, IL 2007. 
tekstów w Dziejach występują również inne, w których Łukasz nie nawiązuje bezpośrednio do motywu Abrahama, jednak w sformułowaniach przez niego użytych można odnaleźć aluzje do starotestamentowej tradycji na temat patriarchy.

Podobnie jak na końcu Ewangelii Łukasza (por. Łk 24,47-49), również początkowe rozdziały Dziejów opisują cykl zdarzeń od zmartwychwstania Jezusa Chrystusa i Pięćdziesiątnicy jako historię współdziałania Boga z Izraelem. Jezus nakazuje rozszerzenie misji za sprawą Ducha Świętego w programowym wersecie Dziejów Apostolskich: gdy Duch Święty zstapi na was, otrzymacie Jego moc i będziecie moimi świadkami w Jerozolimie $i$ w całej Judei, $i w$ Samarii, i aż po krańce ziemi (Dz 1,8). Werset ten zapowiada rozwój narracji Łukasza w całej księdze Dziejów Apostolskich. Poprzedza go informacja, że Jezus nauczał przez czterdzieści dni po zmartwychwstaniu na temat królestwa Bożego (Dz 1,3). Przysłuchujący się temu apostołowie pytają o czas przywrócenia królestwa Izraela $(1,6)$, jednakże Jezus wskazuje, że nie chodzi tu o odnowienie królestwa w sensie politycznym ${ }^{16}$ : Nie wasza to rzecz znać czasy $i$ chwile, które Ojciec ustalit swoja władzq (1,7). Potem następuje zapowiedź zstąpienia Ducha Świętego i nakaz misji po krańce ziemi $(1,8)$. Zwraca się uwagę, że w Łukaszowej narracji $\mathrm{z}$ rozszerzeniem misji łączy się motyw odnowienia Izraela. Misja rozpoczyna się od Izraela, a kończy na zbawieniu pogan ${ }^{17}$. Dar Ducha jest cechą czasów ostatecznych, potwierdza to proroctwo Joela cytowane w Dz 2,17-21. Zesłanie Ducha podczas Pięćdziesiątnicy jest wydarzeniem eschatycznym ${ }^{18}$, a zbawienie zarówno Żydów, jak i pogan przychodzi nie przez wyzwolenie polityczne, lecz przez przebaczenie grzechów i nawrócenie. Od początku relacji $(1,8)$ Łukasz nie odnosi bowiem eschatycznej realizacji obietnicy Boga danej Abrahamowi do sytuacji politycznej, czyli powstania niezależnego państwa Izrael, ani też do zajęcia Ziemi Obiecanej. Działalność Ducha przypomina „Ducha Izraela nowego Exodusu”, które przynosi odnowienie Izraela w dniach ostatecznych ${ }^{19}$. Podobnie jak w słowach do Abrahama z Rdz, tak w tych wypowiedziach jest wskazany kierunek rozszerze-

${ }^{16}$ Zob. C.K. Barrett, The Acts of Apostles, t. 2, Edinburgh 1998, 76.

${ }^{17}$ J. Jerwell, Die Apostelgeschichte, Gottingen 1998, 114. Podkreśla, że Łukasz od początku ukazuje Jezusa jako króla Dawidowego ( $Ł k$ 1,32-33 por. 1,67-75), jako pocieszenie dla Izraela (Łk 2,25), ,chwałę ludu Twego, Izraela” (Łk 2,32), „upadek i powstanie wielu w Izraelu” (2,34), a także „wyzwolenie Jerozolimy” (Łk 2,38). Dodatkowo w towarzystwie apostołów mówi o przekazaniu im królestwa (Łk 22,29).

${ }^{18}$ W. Rakocy, „Będziecie moimi świadkami...” (Dz 1,8), w: Dzieje Apostolskie, Listy św. Pawła (WMWKB 9), red. J. Frankowski - S. Mędala, Warszawa 1997, 55.

${ }^{19}$ M. Turner, Power from on High (Journal of Pentecostal Theology. Supplement Series 9), Sheffield 1996, 302. 
nia zbawienia w kategoriach etnicznych, czyli z Żydów na pogan; zakłada się także poszerzenie geograficzne - od Jerozolimy aż po krańce świata ${ }^{20}$. Ukazane przez Łukasza rozszerzenie się chrześcijaństwa może być pojmowane jako rozszerzanie się perspektywy błogosławieństwa Bożego udzielonego Abrahamowi w związku z zawartym z nim przymierzem.

\subsection{Abraham w nauczaniu Piotra}

Wprawdzie w pierwszej mowie Piotra $(2,14-36)$ nie ma bezpośredniego odniesienia do Abrahama, można jednak odnaleźć w niej aluzje do patriarchów. Piotr zwraca się przede wszystkim do Żydów, jednak dominuje tu aspekt uniwersalny. Cytując Jl 3,5 za Septuagintą ${ }^{21}$, Piotr oświadcza, że zanim nadejdzie dzień Pański, każdy, kto będzie wzywać imienia Pańskiego, będzie zbawiony (2,21). Od czasów Amosa „dzień Pański” to termin określający nadejście ery mesjańskiej, u Joela powiązany z sądem i zapowiedzią wszystkich zbawieniem wybranych, to jest tych, którzy będą wzywać imienia Pańskiego ${ }^{22}$. Cytat ten nasuwa również skojarzenia z tekstami ${ }^{23}$, w których Abraham i Izaak wzywają imienia Jahwe $^{24}$. Dalsza część mowy Piotra (2,22-26) wskazuje, że Boży plan spełnił się przez życie, śmierć, zmartwychwstanie i wywyższenie Mesjasza Dawidowego, Zbawiciela, Jezusa, o którego przyjściu świadczą Pisma. Przypominając przesłanie opowiadania o dzieciństwie Jezusa i posługę Jana Chrzciciela, Piotr mówi o obietnicy złożonej Izraelowi (2,39: Bo dla was jest obietnica i dla dzieci waszych, i dla wszystkich, którzy sq daleko, a których powoła Pan Bóg nasz). Słuchacze Piotra powinni się nawrócić i przyjąć chrzest w imię Jezusa na przebaczenie grzechów, aby stać się wspólnotą napełnioną Duchem Świętym. Powiązanie z zesłaniem Ducha Świętego, podobnie jak w tekstach wcześniejszych ${ }^{25}$, wskazuje na perspektywę zbawienia wszystkich narodów.

Pewne analogie do błogosławieństwa Abrahama można dostrzec również w spotkaniu Żydów z diaspory w dniu Pięćdziesiątnicy. Może ono przypominać rozprzestrzenianie i eschatyczne spotkanie potomków Abrahama.

${ }^{20}$ T.S. Moore, „To the End of the Earth”: the Geographical and Ethnic Universalism of Acts 1:8 in Light of Isaianic Influence on Luke, JETS (1997) 397-398.

${ }^{21}$ Jeden z 24 cytatów Starego Testamentu w Dz. Wszystkie z nich występują w mowach i pochodzą z LXX (z wyjątkiem 8,32). Zob. E. Dąbrowski, Dzieje Apostolskie. Wstęp - przekład z oryginału - komentarz (PŚNT 5), Poznań 1961, 244.

${ }^{22}$ Tamże.

${ }^{23}$ H.M. Kim, „From Israel to the Nations”, 338.

${ }^{24}$ Zob. Rdz 12,8; 13,4; 21,33 - Abraham; Rdz 26,25 - Izaak.

${ }^{25}$ Zob. Łk 3,16; 24,49 i Dz 1,5.8. 
Mowy Piotra wykazują również pewną ciągłość. Widać to, jeśli się weźmie pod uwagę mowę z dnia Pięćdziesiątnicy i mowę wygłoszoną w krużganku Salomona (3,11-26). W drugiej części tej mowy (Dz 3,17-26) Piotr powraca do tematów przedstawionych w czasie zesłania Ducha Świętego. Zakończenie drugiej mowy stanowi w pewien sposób podsumowanie obu wystąpień Piotra. Jest tu bezpośrednie nawiązanie do obietnicy Bożej danej Abrahamowi i jego potomstwu i do błogosławieństwa wszystkich narodów ziemi (Dz 3,25). Podwójne znaczenie Abrahamowej obietnicy zostało przedstawione w mowie Piotra w kontekście zesłania Ducha Świętego, które jest uważane za początek widocznego spełnienia obietnicy Boga danej Abrahamowi ${ }^{26}$. W prezentacji Łukasza zstąpienie Ducha Świętego wyznacza ważny krok w realizacji Bożego planu zbawienia Izraela i innych narodów - krok, który daje początek nowej wspólnocie eschatycznej jednego ludu Bożego.

Wylanie Ducha Świętego w dniu Pięćdziesiątnicy na 120 uczniów stanowi realizację zapowiedzi Jezusa. Mowa, którą Piotr wygłosił przy tej okazji, zawiera wiele cytatów ze Starego Testamentu, które, oprócz odniesień do narodu Izraela, mają także walor uniwersalny. Co więcej, mowa ta łączy motyw Dawida, Mojżesza i Abrahama, świadcząc o ciągłości Bożego planu zbawienia. Dowodzi tego zarówno odbudowa Izraela, jak i zbawienie wszystkich ludzi.

\subsubsection{Bóg ojców a uwielbienie Stugi (Dz 3,13)}

Pierwsze wyraźne odniesienie do Abrahama występuje w Dziejach Apostolskich w drugiej mowie Piotra wygłoszonej po uzdrowieniu chromego żebraka w portyku Salomona (Dz 3,11-26). Odnośne wzmianki znajdują się na początku (w. 13) i na końcu wystąpienia (w. 25). O ile w Dz 1-2 można wskazać pewne ślady, że zbawienie i formacja eschatycznego ludu są oparte na obietnicy Boga danej Abrahamowi, to w drugiej mowie Piotr w bezpośredni sposób wskazuje na związek pomiędzy tymi eschatycznymi wydarzeniami a przymierzem Abrahama, przypominając Bożą obietnicę błogosławieństwa: w potomstwie twoim wszystkie narody ziemi (Dz 3,25).

Dz 3,13 Bóg naszych ojców, Bóg Abrahama, Izaaka i Jakuba, uwielbit Sługe swego, Jezusa, wy jednak wydaliście Go i zaparliście się Go przed Piłatem, gdy postanowit Go uwolnić.

${ }^{26}$ Oprócz przymierza Noego i przymierza na Synaju, w tradycji żydowskiej (Jub 15,1-22) Święto Pierwszych Zbiorów zostało powiązane z przymierzem Abrahama. 
Po uzdrowieniu chromego Piotr przemawia do mieszkańców Jerozolimy, którzy zebrali się przy świątyni. Najpierw Piotr odrzuca jakiekolwiek pojęcie nadprzyrodzonej mocy albo pobożności jako źródło uzdrowienia, przypisując cud wyłącznie mocy Bożej. Piotr mówi jedynie słowami Starego Testamentu. Bóg Abrahama, Izaaka i Jakuba, Boga naszych ojców - to uroczyste określenie Boga, którego początki sięgają teofanii w krzewie gorejącym w Wj 3,6.1527. Formuła ta to zasadnicza charakterystyka Pana jako Boga przymierza zawartego z Abrahamem i jego potomkami.

Za pomocą wyrażenia uwielbit Stuge swego Jezusa - Piotr wyjaśnia, jak to się stało, że chromy znów może chodzić. Odwołuje się do działania Bożego, które miało miejsce dopiero co pośród nich. Cud zdarzył się dlatego, że Jezus został uwielbiony. Przebywając w miejscu swego uwielbienia, Jezus obdarzył uczniów władzą występowania w Jego imię i dokonywania potężnych dzieł, których On również dokonywał, kiedy jeszcze przebywał cieleśnie wśród nich.

Mówiąc o uwielbieniu Jezusa, które nastąpiło w konsekwencji Jego uniżenia i śmierci, Piotr posługuje się językiem zaczerpniętym ze świata pojęć i obrazów ukazujących posłusznego i cierpiącego Sługę Jahwe (Iz 52,13-53,12). W początkowym fragmencie czytamy: „Oto mój Sługa [...] zostanie wyniesiony

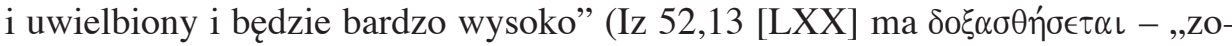
stanie uwielbiony", podczas gdy Dz 3,13 mają є̇ $\delta o ́ \xi \alpha \sigma \in \nu$ - uwielbit). Postać Sługi wywarła bardzo głęboki wpływ na myśl i język Nowego Testamentu ${ }^{28}$.

Piotr, podobnie jak prorok, rozpoczął swą przemowę wskazaniem, że Sługa został uwielbiony przez Boga, a następnie wrócił do opowiadania o Jego cierpieniach. Bóg uwielbił swego Sługę - mówi Piotr - kiedy jednak był w waszych rękach, wy przekazaliście Go na sąd Rzymianom i choć rzymski prokurator był skłonny Go uwolnić, wy przemawialiście przeciwko Niemu.

${ }^{27}$ Określenie to F.F. Bruce nazywa „uświęconym językiem liturgicznym”. Tenże, The Book of the Acts, Grand Rapids, MI 1988, 80n. Modlitwa 18 błogosławieństw rozpoczyna się od inwokacji: „Błogosławiony jesteś, o Panie, Boże nasz i naszych ojców, Boże Abrahama, Boże Izaaka i Boże Jakuba”.

28 Por. Dz 8,32-35. Po raz pierwszy zostaje postać Sługi przywołana w Ewangeliach w scenie chrztu. Głos z nieba, który odezwał się podczas chrztu Jezusa, zwrócił się do Niego słowami z Iz 42,1. Jest to miejsce, kiedy u proroka po raz pierwszy jest mowa o Słudze: „Oto Mój Syn, którego podtrzymuję, Mój wybrany, w którym Moja dusza ma upodobanie” (Mk 1,11; par. Łk 3,22), gdzie słowa z Iz 42,1 poprzedza jeszcze: „Tyś Mym synem” z Ps 2,7. Kryje się tu założenie utożsamienia Sługi z Mesjaszem Dawidowym. F.F. Bruce, The Book of the Acts, 80n. 


\subsubsection{Synowie proroków i przymierza Abrahama (Dz 3,25)}

W dalszej części mowy Piotr przywołuje profetyczne zapowiedzi Chrystusa, które rozpoczyna, wskazując Mojżesza (3,22), następnie Samuela i wszystkich późniejszych proroków $(3,24)$. Na uwagę zasługuje Samuel wymieniony z imienia po Mojżeszu, choć trudno wskazać jakieś proroctwo Samuela, które mogłoby się odnosić do Jezusa. Jednakże to Samuel był tym prorokiem, który namaścił Dawida na króla i mówił o ustanowieniu jego królestwa ${ }^{29}$, zaś obietnice złożone Dawidowi wypełniły się ostatecznie w osobie Jezusa (por. 13,34). W Nim też znalazły wypełnienie wszystkie zapowiedzi proroków (por. 10,43). W tym kontekście Piotr po raz drugi nawiązuje do Abrahama i motywu przymierza.

Dz 3,25 Wy jesteście synami proroków i przymierza, które Bóg zawart z waszymi ojcami, kiedy rzekt do Abrahama: Błogosławione będq w potomstwie twoim wszystkie narody ziemi.

Izraelici, którzy stali, przysłuchując się Piotrowi, zostali nazwani „synami proroków". Piotr nie odwołuje się tu do określenia oznaczającego grupę zawodową proroków, lecz wskazuje, że są oni spadkobiercami obietnic złożonych przez Boga za pośrednictwem proroków i które wypełniły się na ich oczach ${ }^{30}$. W ten sposób oni również stali się „synami przymierza”, które Bóg zawarł z Abrahamem. Słuchacze Piotra są dzięki temu wyjątkowi, ponieważ żyją po to, by ujrzeć dzień, kiedy przymierze to zrealizowało się w Chrystusie: „Błogosławione będą w potomstwie twoim wszystkie rodziny ziemi”31. W ten sposób Łukasz wskazuje ideę posłannictwa do pogan ${ }^{32}$. Skoro Chrystus był potomkiem Abrahama, przez którego przyszło to błogosławieństwo, i skoro obejmowało ono „wszystkie rodziny na ziemi”, to za pierwszych, którzy mogli się nim cieszyć, uznano oczywiście członków rodziny Abrahamowej. Rozwinięcie tej myśli jest w 3,26: „Dla was w pierwszym rzędzie wskrzesił Bóg Sługę swego i posłał Go, aby błogosławił każdemu z was w odwracaniu się od grzechów". Widać tu nie tylko kolejność udzielania błogosławieństwa, ale także jego przynależności. Najpierw Bóg skierował je do Izraelitów i pośród nich wyniósł swego Sługę Jezusa, wybrał Go na ich przywódcę i oswobodziciela, tak

${ }^{29}$ Zob. 1 Sm 13,14; 15,28; 16,13; 28,17.

${ }^{30}$ F.F. Bruce, The Book of the Acts, 87.

${ }^{31}$ Tekst ten stanowi połączenie przekładu LXX Rdz 12,3: „w tobie błogosławione będą wszystkie rodziny na ziemi” i LXX Rdz 22,18: „w twoim potomstwie błogosławione będą wszystkie narody na ziemi”. Tamże, 87.

${ }^{32}$ Por. zastosowanie tej samej obietnicy przez Pawła w Ga 3,8-9.16-29. 
jak przed wiekami wyniósł Mojżesza ${ }^{33}$. Jako obiecany potomek Abrahamowy Jezus przyszedł, by obdarować ich najobfitszym błogosławieństwem Bożym i uwolnić od grzechów. Kiedy Bóg Go posłał, nie zwrócili na Niego uwagi, więc niech to zrobią teraz, kiedy Bóg, okazując im łaskę i przebaczenie, daje im drugą szansę, bo inaczej stracą błogosławieństwo przymierza.

Mowa Piotra z Portyku Salomona ściśle łączy się z jego wcześniejszą mową wygłoszoną w dniu Pięćdziesiątnicy. Język obu wystąpień, mimo iż były skierowane do słuchaczy żydowskich, przenika duch powszechnego zbawie$n^{34}{ }^{34}$. Oświadczenie Piotra, iż Boża obietnica dana Abrahamowi dotyczy przede wszystkim mieszkańców Jerozolimy, a następnie wszystkich narodów na ziemi (3,25-26), odzwierciedla kolejność, jaka występuje w opowiadaniach o Abrahamie. Kolejność tę potwierdzają następne wypowiedzi Pawła (Dz 13,16-50; 26,1-32) i Jakuba (Dz 15,13-18), którzy argumentują na rzecz odbudowy Izraela i zbawienia pogan, przytaczając lub nawiązując do wielu tekstów Starego Testamentu. Wskazanie na rzecz „otwartej” misji Kościoła nie opiera się tylko na jednym konkretnym tekście ST, lecz daje mu świadectwo całe Pismo św., począwszy od pierwszej obietnicy Bożej danej Abrahamowi, Izaakowi i Jakubowi (Dz 3,13) ${ }^{35}$.

\subsection{Motyw Abrahama w mowie Szczepana}

Również mowa Szczepana $(7,1-53)^{36}$ wskazuje na fundamentalny charakter Bożej obietnicy danej Abrahamowi. Realizacji tej obietnicy Izrael doświadczył już w wydarzeniach Wyjścia $(7,17)$ i w dynastii Dawidowej $(7,46-47)$, jednakże jej ostateczne wypełnienie ma się dokonać wraz z przyjściem „Sprawiedliwego” (7,52), który będzie prorokiem jak Mojżesz (7,37; por. 3,22).

${ }^{33}$ Por. Dz 5,30; 13,33 .

${ }^{34}$ Wspomniany cyt. J1 3,5 [LXX] w Dz 2,21 (kto wezwie imienia Pańskiego) i odwołanie się do przymierza Abrahamowego w Dz 3,25 (wszystkie narody na ziemi) z jednej strony nawiązuje do uniwersalnej wizji zbawienia ukazanej w $Ł \mathrm{k}(2,32 ; 3,6 ; 24,27)$, a $\mathrm{z}$ drugiej przygotowuje do późniejszej misji w pełnym wymiarze skierowanej do pogan, która rozwija się w trakcie narracji Dz.

${ }^{35}$ H.M. Kim, ,From Israel to the Nations”, 415.

36 Mowę tę nazywa się często „obroną Szczepana”, względnie ,apologią”. Nie jest to mowa obronna w znaczeniu prawnym. Także wystąpienia nie miały nic wspólnego z ewentualnym uwolnieniem od zarzutów przed obliczem Sanhedrynu. Jest to raczej obrona czystego chrześcijaństwa jako religii zamierzonej i pożądanej przez Boga. Szczepan staje się tu prekursorem późniejszych apologetów chrześcijańskich, szczególnie tych, którzy bronili chrześcijaństwa przed judaizmem. Oskarżenia wniesione przeciw Szczepanowi przed sąd mogły być ukazane w sposób tendencyjny, ponieważ Szczepan przytacza pewne szczegóły stanowiące parodię tychże oskarżeń. Zob. F.F. Bruce, The Book of the Acts, 130. Por. E. Dąbrowski, Dzieje Apostolskie, 277. 
Mowa Szczepana to najdłuższa mowa Dziejów Apostolskich. Został w niej ukazany historyczny przegląd dziejów narodu od powołania Abrahama do zbudowania świątyni Salomona. Można ją podzielić na pięć części: 1) Boże postępowanie wobec Abrahama (ww. 2-8); 2) Boże postępowanie wobec Józefa (ww. 9-16); 3) Boże postępowanie wobec Mojżesza (ww. 17-43); 4) Boża obecność wśród niewiernego ludu (ww. 44-50); 5) Wniosek: nieustanne sprzeciwianie się Duchowi Świętemu i jego wysłannikom (ww. 50-53) ${ }^{37}$. Ten zarys wydarzeń epoki patriarchów i pobytu Izraela w Egipcie stanowi wprowadzenie do tematów centralnych, a opowiadanie o Mojżeszu, o jego powołaniu i wędrówce przez pustynię to pośrednia odpowiedź Szczepana na zarzut przemawiania przeciw Mojżeszowi i bezpośrednia na zarzut występowania przeciw Bogu, zaś kontrast między namiotem na pustyni a świątynią jerozolimską (ww. 44-50) jest konkretną odpowiedzią na zarzut przemawiania przeciw świątyni.

\subsubsection{Retrospektywne spojrzenie na Abrahama}

Wiodącym tematem mowy Szczepana jest ciągłe podkreślanie, iż obecność Boża nie ogranicza się do żadnego kraju ani żadnej budowli materialnej. Bóg ukazał się Abrahamowi długo przedtem, zanim patriarcha osiedlił się w Ziemi Świętej, Bóg był z Józefem w Egipcie, a swe Prawo przekazał narodowi wybranemu za pośrednictwem Mojżesza, kiedy jeszcze Izraelici wędrowali przez pustynię. Analogicznie, ludu Bożego nie należy ograniczać do żadnej wspólnoty lokalnej, zaś Bożej obecności pośród Izraelitów bardziej odpowiadał przenośny namiot, jakim posługiwali się na pustyni i w pierwszych latach osiedlenia w Kanaanie, niż trwała struktura z kamienia zbudowana przez króla Salomona. Czas, jaki Izrael spędził na pielgrzymim szlaku - „Kościół na pustyni” - został uznany za epokę zaprowadzania Bożego porządku. Z tej perspektywy (ale nie tylko) Szczepan odzwierciedla nauczanie wielkich proroków ST, mimo że w rzeczywistości Izrael nie dorastał jeszcze do Bożego ideału ${ }^{38}$.

Dz 7,2b-8 Stuchajcie, bracia i ojcowie: Bóg chwały ukazał sie ojcu naszemu, Abrahamowi, gdy żyt w Mezopotamii, zanim zamieszkat w Charanie. I powiedział do niego: Opuść ziemię swojq i rodzinę swoja, a idź do ziemi, którq ci wskaże. Wtedy wyszedt z ziemi chaldejskiej i zamieszkat w Charanie. A stad po śmierci ojca przesiedlit go Bóg do tego kraju, który wy teraz zamieszkujecie.

37 Zob. R.J. Dillon, Dzieje Apostolskie, w: Katolicki komentarz biblijny (PSB), red. R.E. Brown - J.A. Fitzmyer - R.E. Murphy, red. wyd. pol. W. Chrostowski, Warszawa 2001, 1206.

${ }^{38}$ F.F. Bruce, The Book of the Acts, 130. 
Nie dat mu jednak $w$ posiadanie ani piędzi tej ziemi. Obiecał tylko, że da ja $w$ posiadanie jemu, a po nim jego potomstwu, chociaż nie miał jeszcze wtedy syna. Powiedziat Bóg tak: Potomkowie twoi będq wygnańcami na obczyźnie i przez czterysta lat ujarzmit ich jako niewolników, i będq ich krzywdzić. Lecz naród, którego będq niewolnikami, Ja sam sędziq będę, - mówi Pan. Potem wyjdq i będq Mi stużyli na tym miejscu. I zawart z nim przymierze obrzezania. Tak urodzit mu się Izaak, którego obrzezat dnia ósmego, a Izaakowi - Jakub, a Jakubowi - dwunastu patriarchów.

Mowa rozpoczyna się od odpowiedzi Szczepana na pytanie arcykapłana. Przybiera ona formę retrospekcji historycznej, formę głęboko zakorzenioną w tradycji żydowskiej. Wychodząc od epoki patriarchów, Szczepan przypomina swym słuchaczom, że to właśnie w Mezopotamii, z dala od Ziemi Obiecanej, Bóg po raz pierwszy objawił się Abrahamowi ${ }^{39}$.

Szczepan rozpoczyna swoją mowę od podsumowania życia Abrahama z Rdz:

ww. 2-3 powołanie Abrahama w Mezopotamii (Rdz 11,31, 15,7)

cyt. Rdz 12,1

w. 4 posłuszna odpowiedź Abrahama na powołanie ( $\operatorname{Rdz} 12,4-5)$

w. 5 Boża obietnica ziemi (Rdz 12,7)

cyt. $\operatorname{Rdz} 48,4$

ww. 6-7 proroctwo dotyczące pobytu, kłopotów i wyzwolenia Izraela z Egiptu (Rdz 15,12-16)

cyt. Rdz 15,13; Wj 3,12

w. 8 przymierze obrzezania i obrzezanie Izaaka, Jakuba i Dwunastu ( $\operatorname{Rdz} 21,4)$.

Ukazana w ten sposób historia Abrahama odpowiada w pewnym sensie kolejnym wydarzeniom z Rdz $(11,27-25,11)$, jednakże pomija znaczące fragmenty oryginalnej historii, m.in. opowiadania o Locie, Hagar czy o spotkaniu z Melchizedekiem. Mowa Szczepana jasno wskazuje na cel przymierza Abrahama, którym nie jest posiadanie ziemi, lecz oddawanie czci Bogu w tym miejscu $^{40}$.

${ }^{39}$ J. Siker zwraca uwagę, że motyw Abrahama ukazany tutaj różni się od innych wzmianek, ponieważ pojawia się raczej jako powtórne zdefiniowanie kraju w kontekście kultu, nie zaś nawrócenia. Tenże, Disinheriting the Jews: Abraham in Early Christian Controversy, Louisville $1991,124$.

${ }^{40}$ Tamże, 123-124. 
Biblijny wykaz kolejnych działań Abrahama zawiera rozbieżności w stosunku do relacji Pięcioksięgu, zarówno tekstu masoreckiego, jak i Septuaginty. Należy do nich umiejscowienie powołania Abrahama w Mezopotamii (por. Rdz 11,$31 ; 12,1$ ), czas przybycia do Kanaanu (por. 11,26.32; 12,4), a także słowo „dziedzictwo” z w. 5 oraz powiązanie (Wj 3,12) z (Rdz 15,14.16 w w. 7) $)^{41}$.

Opuszczenie ziemi ojczystej i wyruszenie w podróż, której celu początkowo nie znał, było ze strony patriarchy aktem prawdziwej mądrości. Ukazał mu się bowiem „Bóg chwały” (por. Ps 28,3 [LXX]), który wezwał go do wejścia na drogę wiary. Zastosowanie takiego właśnie tytułu Bożego oznacza, że Bóg objawił mu się w chwale w sposób tak przekonujący, że Abraham nie miał innego wyboru, musiał okazać posłuszeństwo. Szczepan twierdzi, że ci, którzy okazują posłuszeństwo wizji niebiańskiej, będą zawsze żyć niezwiązani z konkretnym miejscem na ziemi, zawsze gotowi się przenieść, dokądkolwiek ich Bóg poprowadzi ${ }^{42}$.

W w. 3 pojawia się tekst Rdz 12,1 mówiący o tym, jak po śmierci Teracha w Charanie Bóg zwrócił się do Abrahama, jednakże zarysowany kontekst wskazywałby czas sprzed wyjścia do Charanu, z pierwszego etapu podróży patriarchy.

W ww. 4-5 Abraham miał więc opuścić „ziemię Chaldejczyków” - termin odpowiada „Mezopotamii” (w. 2) - i osiedlić się w Charanie, w górnej części doliny Eufratu, na skrzyżowaniu ważnych szlaków karawan handlowych, które to miejsce na początku II tysiąclecia znane było jako kwitnące i prosperujące miasto. Tam pozostał do śmierci swego ojca, a potem, kierowany przez Boga, kontynuował wędrówkę, aż dotarł do Kanaanu.

Od przybycia Abrahama do Kanaanu Bóg staje się główną postacią wydarzeń, od Jego działań zależy cała obietnica. Aby wzmocnić tę myśl, Łukasz podkreśla, że nawet wtedy Abraham nie otrzymał na własność ani kawałka ziemi, ani potomka ${ }^{43}$. Patriarcha do końca życia mieszkał tam w charakterze osiedlonego cudzoziemca. Abraham zawierzył tylko i wyłącznie samemu słowu Bożemu i zgodnie z nim działał.

Wersety 6-7 zawierają historyczne podsumowanie mowy Szczepana, który cytuje Rdz 15,13-14 wraz ze słowami z Wj 3,12. W ten sposób wskazuje na proroczą zapowiedź kolejnego wydarzenia - opowieść o Józefie (ww. 9-16). Abraham nie tylko nie otrzymał na własność ziemi, ale ponadto jego wiara została wystawiona na próbę, kiedy dowiedział się, że jego potomkowie będą musieli opuścić tę ziemię i zostawić ją komuś obcemu, a sami przez kilka

\footnotetext{
${ }^{41}$ R.J. Dillon, Dzieje Apostolskie, 1207.

${ }^{42}$ F.F. Bruce, The Book of the Acts, 133.

${ }^{43}$ R.J. Dillon, Dzieje Apostolskie, 1207.
} 
pokoleń będą doświadczać ucisku i niewoli (ww. 18-19). Opowieść o Mojżeszu (ww. 20-36) wyjaśnia jednak, że ich wygnanie nie będzie trwałe, lecz w stosownym czasie Bóg ześle im wybawienie od ciemiężycieli i sprowadzi ich z powrotem, by oddawali Mu cześć w ziemi Kanaan pod panowaniem Dawida

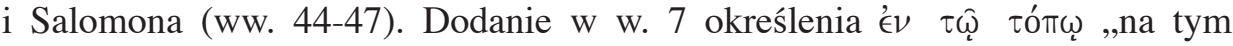
miejscu” nie odpowiada Wj 3,12, gdzie jest „na tej górze” (chodzi o Horeb), ani Rdz 15,16: „powrócą tu”. Wydaje się, że Szczepan chce w ten sposób podkreślić, że obietnica dana Abrahamowi, choć obejmowała oddawanie chwały Bogu na ziemi, nie pokrywała się jednak z czasem wzniesienia świątyni (ww. 47-48) ${ }^{44}$.

Werset 8: zewnętrznym znakiem przymierza zawartego przez Boga z Abrahamem było obrzezanie (Rdz 17,9-14.23-24). Przyjęcie przez Abrahama tego widzialnego znaku na siebie samego i swoich potomków było kolejnym dowodem jego wiary w Boga. Kiedy urodził się Izaak, Abraham obrzezał go w ósmym dniu po narodzeniu ( $\mathrm{Rdz} 21,4)$, a ten znak przymierza przekazywano z pokolenia na pokolenie, od Izaaka do Jakuba, od Jakuba do jego dwunastu synów - protoplastów dwunastu pokoleń izraelskich.

\subsubsection{Abraham w kontekście historii Józefa i Wyjścia}

Dz 7,16 Przeniesiono ich do Sychem i złożono w grobie, który Abraham kupił za srebro od synów Chamora w Sychem.

Werset 16: informacja o przeniesieniu ciał patriarchów po ich śmierci w Egipcie do Sychem nawiązuje do tradycji Abrahama o nabyciu przez niego Hebronu (Rdz 23,17-20, por. 50,13) i kupna Sychem przez Jakuba (Rdz 33,1819, por. Joz 24,32$)^{45}$. Nie zostali oni pochowani w Egipcie, lecz w kraju, który Bóg obiecał ich potomstwu jako dziedzictwo. Obecność ich grobów w Ziemi Obiecanej, tam gdzie już były groby Abrahama i Izaaka, wskazuje, że mimo śmierci w Egipcie, zmarli w wierze (por. Hbr 11,13) ${ }^{46}$. W tym kontekście w w. 17 Szczepan wskazuje na spełnienie obietnic danych Abrahamowi - jest to wyzwolenie przez Boga Izraela z Egiptu $(7,17)$.

Mowa Szczepana w całej narracji Dz stanowi punkt zwrotny, potwierdzając fundamentalny charakter Bożej obietnicy danej Abrahamowi, czyli objęcia przez Izraelitów Ziemi Obiecanej po wyjściu z Egiptu; jednocześnie jednak akcen-

\footnotetext{
${ }^{44}$ Por. tamże.

${ }^{45}$ R.J. Dillon, Dzieje Apostolskie, 1207.

${ }^{46}$ F.F. Bruce, The Book of the Acts, 137.
} 
tuje transcendencję Boga, którego nie ogranicza żadne konkretne miejsce ani poszczególne tradycje.

W dalszej części mowy Szczepana zostaje przedstawione Boże postępowanie wobec Mojżesza (7,17-43). Wersety 17b-19 odnoszą się do Wj 1,7-10 [LXX], podobnie następne fragmenty, choć już luźnej nawiązują do narracji $\mathrm{Wj}$ : ww. 20-22 do Wj 2,2-10; ww. 23-29 do Wj 2,11-22; ww. 30-34 do Wj 3,1-10. W tym ostatnim fragmencie znajduje się ponownie formuła określająca Boga (por. 3,13).

Dz 7,32 Jam jest Bóg twoich przodków, Bóg Abrahama i Izaaka, i Jakuba.

Podobnie jak Wj, tak i tu sam Bóg mówi o sobie jako o „Bogu przodków”, co wskazuje na ciągłość objawienia. Bóg, który objawił się Abrahamowi w Mezopotamii i dał Józefowi wsparcie w czasie pobytu w Egipcie, teraz spotyka się z Mojżeszem na pustyni, daleko od Ziemi Obiecanej. Bóg objawia się już tu, w miejscu, które choć należy do pogan, staje się dzięki temu „Ziemią Świętą" "77. Powraca tu idea przedstawiona przez Piotra w Dz 3,13. Użycie formuły Bóg Abrahama i Izaaka, i Jakuba ponownie podkreśla, że Bóg nie jest ograniczony do jakiegoś miejsca, a obietnica dana Abrahamowi miała na względzie nie posiadanie ziemi, lecz oddawanie czci Bogu.

Szczepan, również podobnie jak Piotr, potwierdza fizyczne pochodzenie Żydów od Abrahama, lecz odrzuca tezę, iż miałoby to wystarczać do zapewnienia Bożego błogosławieństwa. Szczepan kwestionuje również przekonanie o pożytku z trzech najważniejszych elementów judaizmu okresu drugiej świątyni: Prawa, świątyni i obrzezania. Stały się one bardziej symbolami żydowskiej odrębności i przeszkodą dla pogan aniżeli świadectwem Bożego zamiaru błogosławienia Izraelowi i wszystkim narodom na ziemi.

Mowa i męczeństwo Szczepana wyznaczają cezurę w Dziejach Apostolskich. Do tej pory wszystko działo się w Jerozolimie, jednak po śmierci Szczepana wybuchają prześladowania i uczniowie rozpraszają się po Judei i Samarii $(8,1)^{48}$. Rozwój narracji w Dz 8-11 jednoznacznie ukazuje transcendencję Boga jako jedynego Stworzyciela rodzaju ludzkiego i jako kogoś, kto nie zamyka się w żadnych granicach geograficznych czy narodowych. Zbawienie Samarytan $(8,14-25)$, dworzanina etiopskiego $(8,26-40)$ i poganina Korneliusza $(10,1-$

\footnotetext{
${ }^{47}$ Por. tamże, $141 \mathrm{n}$.

48 Por. J. Taylor, Dzieje Apostolskie, w: Międzynarodowy komentarz do Pisma Świętego. Komentarz katolicki i ekumeniczny na XXI w., red. W.R. Farmer, red. wyd. pol. W. Chrostowski, Warszawa 2000, 1380n.
} 
11,18) wskazuje, iż Bogu Izraela obcy jest wszelki ekskluzywizm i nepotyzm ${ }^{49}$. On przyjmuje każdego, kto okazuje Mu bojaźń i czyni to, co słuszne (10,3435). Opowiadania te potwierdzają tezę zawartą w mowie Szczepana, iż Boża obecność, manifestowana wylaniem Ducha Świętego, nie sprowadza się do posiadania świątyni, dysponowania Prawem czy praktykowania obrzezania.

\subsection{Abraham w mowie i nauczaniu Pawła}

W Dziejach Apostolskich Łukasz po raz ostatni nawiązuje bezpośrednio do Abrahama, przytaczając pierwszą mowę św. Pawła wygłoszoną w Antiochii Pizydyjskiej (Dz 13,16-47) podczas pierwszej podróży misyjnej Apostoła (13,114,28). W ww. 13-14a Łukasz podaje informacje na temat podróży Pawła i jego towarzyszy oraz ich przybycia do Antiochii, która była centrum administracyjnym rzymskiej prowincji Galacji w Azji Mniejszej ${ }^{50}$.

Cały opis działalności misyjnej w tym mieście został zawarty w dwóch scenach. Zdarzenia miały miejsce podczas kolejnych dni szabatu. W pierwszej scenie przedstawione jest kazanie misyjne Pawła wygłoszone głównie do Żydów w synagodze (ww. 16-41) oraz reakcja słuchaczy (ww. 42-43). Druga scena to przybycie całego miasta - wszyscy chcieli posłuchać misjonarzy, co doprowadziło do sprzeciwu Żydów i wyrzucenia Pawła z miasta (ww. 44-52).

Pod względem kompozycyjnym mowa Pawła przypomina mowy Piotra i Szczepana. Wydarzenia z dziejów Izraela stają się pomostem do argumentacji prowadzącej do Osoby Jezusa Chrystusa jako celu zapowiedzi prorockich i kulminacją głoszonego przez nich mesjanizmu ${ }^{51}$. Mówca skupił się na idei obietnicy tak charakterystycznej nie tylko dla epoki patriarchów, ale i późniejszej religii Izraela.

Tekst mowy można podzielić na fragmenty za pomocą słów pozdrowienia (ww. 16.26.38), które wyznaczają mniejsze jednostki: 1) podsumowanie historii ST i ery obietnicy (ww. 16-25); 2) naukę o Jezusie jako tym, który zgodnie z Pismem wypełnia obietnicę (ww. 26-37); 3) wezwanie do wiary i obietnica przebaczenia, podsumowujące mowę (ww. 38-41) ${ }^{52}$. Bezpośrednie nawiązanie do Abrahama znajduje się na początku drugiej części mowy, kiedy to pojawia się w kontekście odrzucenia Jezusa przez Żydów z Jerozolimy.

\footnotetext{
${ }^{49}$ Zob. H.M. Kim, „From Israel to the Nations”, 416.

${ }^{50}$ Por. F.F. Bruce, The Book of the Acts, $251 \mathrm{n}$.

${ }^{51}$ Zob. E. Dąbrowski, Dzieje Apostolskie, 343.

52 Zob. R.J. Dillon, Dzieje Apostolskie, 1220.
} 
Dz 13,26-27 Bracia, synowie rodu Abrahama, i ci spośród was, którzy się boja Boga! Nam została przekazana nauka o tym zbawieniu, bo mieszkańcy Jerozolimy $i$ ich zwierzchnicy nie uznali Go, i potępiajac Go wypełnili głosy Proroków, odczytywane co szabat.

Drugą część rozpoczyna uroczysta proklamacja, że orędzie zbawienia zostało skierowane „dla was” (albo „dla nas”, jak zapisano w niektórych starożytnych rękopisach). Podobnie jak Piotr i Szczepan, Paweł stwierdza, iż Żydzi są potomkami Abrahama, któremu jako pierwszemu zostało przekazane orędzie zbawienia. Paweł zwraca jednak uwagę, że zbawienie dotyczy również pogan bojących się Boga. W tym kontekście przekazuje zbawcze orędzie o śmierci i zmartwychwstaniu Jezusa (ww. 27-31). Apostoł zaświadcza, że jest On Mesjaszem, a Jego zmartwychwstanie to wypełnienie obietnicy, jaką Bóg złożył ojcom (ww. 32-37), co jest fundamentem zbawienia nie tylko dla Żydów, ale także „dla każdego, kto wierzy". Apostoł wskazuje słuchaczom, że odpuszczenie grzechów dokonuje się przez Jezusa, i ostrzega ich, aby nie znaleźli się wśród „szyderców”, którzy odrzucają Boga (ww. 38-39) ${ }^{53}$.

W dalszej części poświęconej działalności misyjnej Pawła (od Dz 1428) również można odnaleźć aluzje do motywu Abrahama. Mowa Pawła w Antiochii Pizydyjskiej ukazuje wzór prowadzenia misji, powtarzający się w dalszej działalności Pawła. Rozpoczyna on od głoszenia Ewangelii Żydom, a następnie kieruje się do pogan. Mimo że imię Abrahama nie pojawia się już w Dziejach, to kontynuowanie misji Pawła do Żydów i pogan potwierdza kierunek rozwoju chrześcijaństwa. Wypowiedź Jakuba podczas Soboru Jerozolimskiego oraz późniejsze mowy Pawła potwierdzają dwojakie znaczenie dawnej obietnicy Bożej: odbudowa Izraela i zbawienie pozostałej części ludzkości $(15,17)$. Zarówno mowa Jakuba, jak i mowa obronna Pawła przed Herodem Agryppą (Dz 26,1-32) ukazują, że nadzieja Izraela musi wykraczać poza ograniczenia stawiane przez Żydów, ponieważ Bóg pragnie zbawienia całej ludzkości. Uniwersalny wymiar obietnicy, jaką Bóg złożył ojcom założycielom Izraela, pojawia się również w odpowiedzi na zarzuty, jakie Żydzi wnieśli przeciwko niemu (26,2). Paweł stwierdza, że oto znajduje się przed sądem ze względu na nadzieje, jakq pokłada $w$ obietnicy złożonej przez Boga ich poprzednikom (w. 6). Pawłowa obrona nadziei szybko przekształca się w mowę misyjną. Apostoł wyraża zdziwienie, że jego oponenci nie mogą uwierzyć w zmartwychwstanie. Jeśli wierzą w zmartwychwstanie, jak być powinno zgodnie z przekonaniami faryzeuszów, to nie powinni przekreślać wiarygodności zmartwychwstania Jezusa. W obecnej mowie Paweł sięga do dwóch światów pojęć i obrazów,

${ }^{53}$ J. Taylor, Dzieje Apostolskie, 1387. 
mówi bowiem o sytuacji wcześniejszej i tej po spotkaniu ze zmartwychwstałym Jezusem. Spotkanie to nazywa wizja z nieba (w. 19), dzięki której posiadł nowe zrozumienie nadziei, a jest ona przeznaczona nie tylko dla naszych dwunastu pokoleń (w. 7), ale także dla pogan (Dz 26,20: Lecz nawoływałem najprzód mieszkańców Damaszku i Jerozolimy, a potem całej ziemi Judzkiej, i pogan, aby pokutowali i nawrócili się do Boga, i pełnili uczynki godne pokuty).

W Dziejach Łukasz nie zajmuje się Abrahamem i motywami z nim związanymi tylko za pomocą przytaczania tekstów ST, lecz podąża też śladem schematu biblijnego, w którym znajdują odbicie obszerne tradycje o Abrahamie w myśli i historii Izraela. Sięgając po biblijne i pozabiblijne tradycje o Abrahamie, w Łk-Dz Łukasz prezentuje Boży plan zbawienia przeznaczonego nie tylko dla narodu żydowskiego, ale także dla pozostałej części ludzkości, oraz wskazuje na ciągłość między Izraelem a Kościołem.

W mowach Piotra, Szczepana i Pawła wątkowi Abrahama towarzyszą najważniejsze tematy ST, takie jak motyw Dawidowy i motyw Wyjścia. Łukasz prezentuje narodowe i uniwersalistyczne aspekty błogosławieństw towarzyszących przymierzu jako fundamentalne cechy Bożego planu zbawienia, polegającego na zaniesieniu zbawienia wszelkiemu stworzeniu i wszystkim narodom, począwszy od Izraela. Łukasz wprowadza ciągłość między przeszłością, teraźniejszością i przyszłością oraz ciągłość między Izraelem i poganami jako ludem Bożym zgodnie z Jego planem zbawienia opartym na Bożej obietnicy przymierza danej Abrahamowi.

Wprawdzie Dz konsekwentnie ukazują Boga jako Boga Izraela, ale jednocześnie prezentują Go jako Stworzyciela całego rodzaju ludzkiego, który wykracza poza granice wyznaczone ludzkimi rękoma. W miarę rozwoju narracji w Dz wypełnienie znajduje Boża obietnica złożona Abrahamowi, dotycząca błogosławieństwa potomków Abrahama i wszystkich narodów na ziemi. Fakt, iż Łukasz korzysta z wielu tekstów ST, by wykazać „otwarty” charakter posłannictwa od Boga, uzmysławia, iż za taką fundamentalną charakterystyką Boga i Jego planu zbawienia przemawia całe Pismo św.

Doświadczanie błogosławieństw przez poszczególnych Izraelitów osiąga zwieńczenie w masowych nawróceniach Żydów w dniu Pięćdziesiątnicy i w dalszej działalności uczniów w Jerozolimie (Dz 2,39.41.47; 3,25; 4,4; 5,28), Judei i Samarii $(8,1.14 ; 9,31)$. W miarę rozwoju narracji w Dz misja uczniów obejmuje również pogan, a ich zbawienie zostaje ukazane jako spełnienie Abrahamowych 
błogosławieństw skierowanych do narodów. Stwierdzenie Jezusa w Dz 1,58, będące powtórzeniem oświadczenia z mowy pożegnalnej w Łk 24,44-49, wyjaśnia znaczenie chrztu w Duchu Świętym $(1,5)$. Przyjście Ducha Świętego, które stało się możliwe dzięki śmierci, zmartwychwstaniu i wniebowstąpieniu Jezusa, uzdalnia teraz uczniów do świadczenia o Nim aż po krańce ziemi $(1,8)$. Jak widać, ostatecznym celem przyjścia Ducha Świętego jest posłanie na cały świat naśladowców Jezusa Chrystusa inspirowanych Duchem. Dzieje Apostolskie ukazują wyraźnie, że Bóg Izraela jest Bogiem otwartym i daleki jest Mu wszelki partykularyzm (10,34), ponieważ sam jest jedynym Stworzycielem nieba, ziemi i całego rodzaju ludzkiego (4,24; 14,15-18; 17,25-31).

W ujęciu Łukasza Bóg od początku zamierzał zbawić wszystkich ludzi świadczą o tym minione wydarzenia i dzieła, których dokonał w historii Izraela, jak i całe Pismo św.: Prawo, Prorocy i Psalmy. To poszerzenie misji Łukasz ukazuje w swoim podwójnym dziele według schematu „od Izraela do narodów”. Pierwsze przyjście Jezusa i zesłanie Ducha Świętego mają jeden wspólny mianownik - wypełnienie Bożego planu zbawienia, który ma podjąć Kościół, czyli inspirowana Duchem Świętym wspólnota uczniów Chrystusa ${ }^{54}$.

\footnotetext{
${ }^{54}$ Zob. H.M. Kim, „From Israel to the Nations”, $413 \mathrm{n}$.
} 


\section{Summary}

The Abraham motif plays a significant role in the narrative construction in LukeActs. Luke's frequent use of the Abraham material more than any other NT writings (Gospel of Luke - 15; Acts - 7 times). The memory of Abraham in Luke's writings recalls not only the story of Abraham in Genesis but also a rich tradition embedded in others OT Scriptures and the literature of Second Temple period. The significance of God's promise to Abraham and the subsequent deliverances of Israel according to that promise show not only continuity among communities of Israel in the different times and places, but also the anticipation of the ultimate, especially, eschatological fulfillment of the promise. The promise-fulfillment motif, then, is not limited to a single prediction or predictions, but rather fundamentally characterizes God's plan of salvation for Israel and for the nations, which is firmly based upon his eternal covenant promise made to the patriarchs. The article has examined texts containing direct references, allusions, and echoes of the Abraham motif in Acts $(3: 13.25$; 7:2.16-17. 32; 13:26). Abraham is explicitly mentioned only in three speeches in Acts, the fact that those speeches of Peter (3:12-26), Stephen (Acts 7:2-53), and Paul (Acts 13:16b-47) are the three most important speeches in Acts indicates the significance of the Abraham motif. These three speeches bring out not only the national aspect of the Abrahamic covenant but also the universal aspect. By adopting the pattern found in the Abraham narrative in Genesis, which progresses from a national covenant blessing to a universal one, Luke establishes continuity between the past, present, and future as well as continuity between Israel and the Gentiles as one people of God in God's plan of salvation. As the narrative develops in Acts from Israel to nations, the mission of the disciples expands to the Gentiles and their salvation is viewed as a fulfillment of Abrahamic blessings to the nations. 
